\title{
Observation on the Us es of Mobile Phones to Support Informal Learning
}

\author{
http://dx.doi.org/10.3991/ijim.v6i4.2223 \\ Y.A. Rahim, A.N. Che Pee and M.A. Othman \\ Universiti Teknikal Malaysia Melaka, Melaka, Malaysia
}

\begin{abstract}
This paper explores how a group of undergraduate students in one of the university in South of Malaysian use their mobile phones to perform informal learning activities related to the content of their courses outside the classroom. The paper also addresses the usefulness of informal learning activities to support students' learning. The study adopts an exploratory case study design and uses two methods of data collection including questionnaires and interviews. Main findings suggest that students performed informal learning activities mostly from office, home, interacting mainly with classmates. It also shows that students were in control of their informal learning activities without tutor or SMEs' input. However, it was found that students used only a limited number of applications but these were considered useful to their learning. The paper contributes to a discussion of the implications of training and instructional support to help students to take more advantage of mobile phone applications to support informal learning. The conclusion is discussed about the further research in this domain.
\end{abstract}

Index Terms-Mobile technologies, mobile phones, informal learning, curriculum.

\section{INTRODUCTION}

Mobile technologies such as mobile phones, Smartphone, iPads and iPods are contributing to new forms of learning which are no longer confined to the classroom environment (Traxler 2009). Students can access and share information, communicate, collaborate and learn anywhere and at any time (Looi et al. 2010). As users of mobile devices become increasingly widespread worldwide, it is likely that students will use them to support informal learning (Clough et al. 2009) and also for the formal learning as an extra supporting learning environment.

However, while informal learning has a strong connection with mobile technologies (Kukulska-Hulme and Pettit 2009), this concept carries many meanings (Sefton-Green 2004) and needs clarification for the purpose of this paper. Some researchers view informal learning as having no structure in place and no teacher (e.g. Laurillard 2007; Livingstone, 2000). In the absence of a teacher, the learning goals are determined by the students (Cook et al. 2008). Others see informal learning as intentional, where the goals and processes of learning are explicitly defined in advance by the individual or unintentional where the goals and the learning processes develop as a learning opportunity arises (Vavoula 2004; Jokisalo and Riu 2009). In facts, intentionally or unintentionally, learning may still take place and it can happen at any time and in any location, and may involve individual or joint efforts (Laurillard 2007; Looi et al. 2010). In addition, students may engage in a broad range of informal learning activities. These activities can be viewed as not having a direct link to curriculum formats. They can also be viewed as leisure activities or as support for formal education but performed in informal settings (Sefton-Green 2004; Mann 2008).

Research has shown that students used mobile technologies to support informal learning. For example, Clough et al. (2009) explored how participants used their mobile technologies to support informal learning. It was found that participants engaged in a wide range of informal activities such as exchanging data between devices, posting and answering questions to a web forum and posting wiki entries. Similarly, Kukulska-Hulme and Pettit (2009) investigated how participants used mobile technologies such as mobile phones or smartphone to perform informal learning specifically related to work, teaching, learning, leisure, entertainment and social interactions. For example, findings revealed that mobile phones were largely used in social interactions followed by work related activities, while YouTube, Twitter, Facebook were mostly used for entertainment or to invite social groups.

As discussed above, our focus is on informal learning activities that are related to the students' studies. This investigation expects to provide a comprehensive analysis of students' experience of using mobile phones outside the classroom. It also expects to help instructors to maximize the opportunities for students regarding the benefits of informal learning.

\section{RESEARCh Methodology}

We adopted an exploratory case study design (Yin 2003) to investigate how students use mobile phones to perform informal learning activities outside the classroom and the impact of these activities on student learning. As noted by Cohen et al. (2007), exploratory case studies act as preliminary studies when it is not yet clear how to measure the phenomenon (Lynn 1991). We considered this approach the most appropriate as it would allow us to experiment and clarify our methods of data collection before implementing a large scale study.

Methods of data collection consisted of questionnaires and interviews. Feedback received helped simplify and clarify some of the questions and statements. The design of the tools was guided by Cheung and Hew's (2009) framework and study aims. These tools are described next. 


\section{A. Questionnaire}

Designed and administered an anonymous questionnaire to the students to obtain information on key themes including 1) demographic information, 2) mobile phone ownership and kinds of models, 3) uses of mobile phones to perform informal learning activities, 4) context of informal learning, and 5) usefulness of informal learning activities to student learning. The design of the questionnaire used a mixed format. It included a series of statements about student usage of mobile phone applications and a rating scale (frequently (1), sometimes (2), rarely (3), never (4), and never used (5). Another scale to ascertain the usefulness of informal activities ranged from very useful (1) to not at all useful (4) or did not use (5). The questionnaire also included ticking the boxes (e.g. yes or no), multiple choice questions (e.g. age group) and open-ended questions. Data were collected at one point in time and all students completed and returned the questionnaire $(\mathrm{N}=15)$. We chose to use a questionnaire as a primary tool because it allowed structured questions which would give us an overview of participants' engagement in informal learning activities using mobile phones.

\section{B. Interview}

Five students were randomly selected to participate in a one-to-one, face-to-face semi-structured interview. The interviews were used to complement the other sources used in the study. They were not used as representative; rather they aimed to explore in more depth student perceptions of informal learning activities using mobile phones. The interviews covered the following key topics:

- Examples of informal learning activities using mobile phones,

- usefulness of the learning activities, and most/least used applications to perform informal learning.

\section{RESUlTS AND DISCUSSIONS}

Quantitative analysis of close-ended questions from student questionnaires consisted of, as suggested by Cohen et al. (2007), assigning a code number to each closed question. We develop a code frame for all questions with software SPSS version 15 was used to process the responses from the questionnaires. The percentages for each of the quantitative variables covered in the questionnaire were then calculated. The quantitative results were organized according to the framework that guided the study as explained earlier in this paper.

Qualitative analysis of the interviews and open-ended questions from the questionnaire were guided by the study aims as well as Cheung and Hew's (2009) categories. Analysis consisted of one of the researchers reading from all the documents first. Then she manually coded the different documents that seemed to exemplify Cheung and Hew' categories (e.g. communication tools). Some codes emerged inductively, such as context of informal learning.

The presentation of data analysis in this section is organized by the research questions. According to Cohen et al. (2007), this approach is an effective way of organizing data, as it brings together all the data relevant to the particular question. The quantitative data for each question sought in the study are presented first followed by qualitative data.

\section{A. Results from quantitative data}

All students participating in the study owned a mobile phone, with $98 \%$ having phones that could access the internet. From the questionnaire, the result shows that the most popular place where students carried out informal activities using the mobile phone was an office, with 53\% performing informal learning frequently, follow by at home $45 \%$ and the balance was other places like shopping centers, sports complex and others. Among the key applications, Twitter, Facebook and SMS were used frequently with all of the participants or students, either to shock, sharing or exchange either send or receive information. The phone calls, is the worst application that they do as a medium to discuss course content outside the classroom.

\section{B. Results from qualitative data}

Qualitative analysis shows that students used their mobile phones outside the classroom mainly to contact classmates to discuss the content of their courses. Issues students discussed with classmates included course assignments, projects, questions, getting ideas, information and clarifications of issues. For example, the open-ended questions from the questionnaire revealed that some students contacted their classmates using the twitter, Facebook or phone call application while some used SMS. A few mentioned using social network, SMS and phone calls. In addition, although not being specific about whether they used Twitter, Facebook or SMS or phone calls, a few students said they used their mobile phones to discuss with their classmates issues related to projects, to get information about exams, to discuss homework and "some things that I do not understand in the class...".

\section{CONCLUSIONS}

This paper discussed how a group of undergraduate students in south of Malaysia have used iPads, android or mobile phones to support informal learning outside the classroom. However the group of students was engaged in informal learning activities connected to the content of their courses, with the limited of a few familiar applications, such as SMS and phone calls but those applications were perceived as useful to their learning. In order to take advantage of the applications available on their mobile phones to support informal learning, it was recommended that students should attend the proper training. The tutor or SMEs or Instructors can help them to develop more awareness of the potential of mobile phones to support informal activities. Additionally, findings suggest that students were in control of their informal learning activities without teachers' directions. These students, whether using mobile phone applications frequently or occasionally outside the classroom like in the office, home or cafe, were in fact supporting their formal education.

\section{ACKNOWLEDGMENT}

Authors would like to thank Universiti Teknikal Malaysia Melaka for piloting this project and also sponsoring to this journal. 


\section{REFERENCES}

[1] Bradley, C., \& Holley, D. (2010). An analysis of first-year business students' mobile phones and their use for learning. In Proceedings of The 17th Association for Learning Technology Conference (ALT-C 2010). University of Nottingham, UK, 7-9 September.

[2] Brandt, E., Hillgren, P., \& Bjorgvinsson, E. (2003). Self-produced video to augment peer-to-peer learning. In Proceedings of Mlearn 2003 Learning with Mobile Devices. 19-20 May, London.

[3] Cheung, W., \& Hew, K. (2009). A review of research methodologies used in studies on mobile handheld devices in K-12 and higher education settings. Australasian Journal of Educational Technology, 25 (2), 153-183.

[4] Churchill, D., \& Churchill, N. (2008). Educational affordances of PDAs: a study of a teacher's exploration of this technology. Computers \& Education, 50, 1439-1450. http://dx.doi.org/ 10.1016/j.compedu.2007.01.002

[5] Clough, G., Jones, A., McAndrew, P., \& Scanlon, E. (2009). Informal learning in online communities of mobile devices enthusiasts. In M. Ally (Ed.), Mobile learning: Transforming the delivery of education and training (pp. 100-112). Athabasca: Athabasca University Press.

[6] Cohen, L., Manion, L., \&Morrison, K. (2007). Research methods in education (6th ed.). London: Routledge.

[7] Cook, J., Pachler, N., \& Bradley, C. (2008). Bridging the gap? Mobile phones at the interface between formal and informal learning. Journal of the Research Center for Educational Technology, 4(1), 3-18.

[8] Kukulska-Hulme, A., \& Pettit, J. (2009). Practitioners as innovators: Emergent practice in personal mobile teaching, learning, work and leisure. In M. Ally (Ed.), Mobile learning: Transforming the delivery of education and training (pp. 135155). Athabasca: Athabasca University Press.

[9] Laurillard, D. (2007). Pedagogical forms for mobile learning. Framing research questions. http://eprints.ioe.ac.uk/627/1/ Mobile_C6 Laurillard.pdf. Accessed 20 August 2009.

[10] Livingstone, D. (2000). Exploring the icebergs of adult learning. http://www.oise.utoronto.ca/depts/sese/csew/nall/res/cjsaem.pdf. Accessed 10 March 2009.

[11] Looi, C., Seow, P., Zhang, B., So, H., Chen, W., \& Wong, L. (2010). Leveraging mobile technology for sustainable seamless learning: a research agenda. British Journal of Educational Technology, 41(2), 154-169. http://dx.doi.org/10.1111/j.14678535.2008.00912.x

[12] Mann, S. (2008). The Emergence of Mobile Devices Influencing Learning from the Viewpoint of Convergences. In Proceedings of Wireless, Mobile, and Ubiquitous Technology in Education. Fifth IEEE International Conference (pp. 191-193). Sydney, Australia. 23-26 March.

[13] Padgett, D. (1998). Qualitative methods in social work research: Challenges and rewards. London: Sage. Patten, B., ArnedilloSánchez, I., \& Tangney, B. (2006). Designing collaborative, constructionist and contextual applications for handheld devices. Computers \& Education, 46(3), 294-308.

[14] Pierroux, P. (2008). Extending meaning from museum visits through the use of wikis and mobile blogging. Conference paper at International Perspectives in the Learning Sciences (ICLS 2008), Utrecht.

[15] Santos, I. (2010). Finding opportunities to use SMS in the classroom. In Proceeding of IADIS Mobile Learning International Conference (pp. 45-52), Porto, Portugal, 19-21 March.

[16] Scanlon, E., Jones, A. \& Waycott, J. (2005) Mobile technologies: prospects for their use in learning in informal science settings. Journal of Interactive Media in Education, 25.

[17] Sefton-Green, J. (2004). Literature review in informal learning with technology outside school. http://www.futurelab.org.uk/ resources/documents/lit reviews/Informal Learning Review.pdf. Accessed 5 May 2009.
[18] Sharples, M., Milrad, M., Arnedillo-Sánchez, I., \& Vavoula, G. (2007). Mobile learning: Small devices,big issues. http://telearn.noekaleidoscope.org/warehouse/KAL_Legacy_Mobi le Learning (001143v1).pdf. Accessed 15 June 2009.

[19] Thornton, P., \& Houser, C. (2004). Using mobile phones in education, In Proceedings of the 2nd IEEE International Workshop on Wireless and Mobile Technologies in Education (WMTE’04) (pp. 2-10), Taiwan.

[20] Vavoula, G. (2004). KleOS: A knowledge and learning organisation system in support of lifelong learning. PhD Thesis. UK: University of Birmingham.

[21] Vavoula, G., Sharples, M., Rudman, P., Lonsdale, P., \& Meeket, J. (2007). Learning bridges: A role for mobile technologies in education. http://telearn.noe-kaleidoscope.org/open-archive/file? ETMagazine SUBMITTED (001557v1).pdf. Accessed 5 March 2010.

[22] Yin, R. (2003). Applications of case study research (2nd ed.). London: Sage Publications.

[23] Traxler, J. (2009). Current state of mobile learning. In M. Ally (Ed.), Mobile Learning: Transforming the delivery of education and training (pp. 9-24). Athabasca: Athabasca University Press.

\section{AUTHORS}

Yahaya Abd. Rahim was born at Johor Bahru, Johor, Malaysia. He received his Degree Bachelor of Information Technology (Database) from Universiti Utara Malysia (UUM) on 1995 then he received his Master's Degree in Information Technology (Management) from Universiti Teknologi Malaysia on 2001. In September 2003 he joined Universiti Teknikal Malaysia Melaka (UTeM) as a Lecturer at Fakulti Teknologi Maklumat dan Komunikasi (FTMK) and continues his $\mathrm{PhD}$ in Information Technology at UTeM. His research currently on Data Privacy in Network Environment.

Ahmad Naim Chee Pee was born at Ampang, Selangor, Malaysia. He received Degree Bachelor of Science in Computer Science (Software Engineering) from Victoria University of Technology, Australia. He received his Master's Degree in Computer Science (Multimedia) from Universiti Putra Malaysia (UPM) on 2003. In June 2003 he joined Universiti Teknikal Malaysia Melaka (UTeM) as a Lecturer at Fakulti Teknologi Maklumat dan Komunikasi (FTMK). He received his $\mathrm{PhD}$ in Computer Science (Computer Games) on December 2011. Currently he is working on computer games development.

Mohd Azlishah Othman was born on $21^{\text {st }}$ October 1980 at Johor Bahru, Johor, Malaysia. He received Degree Bachelor of Engineering in Electrical Engineering (Telecommunication) from Universiti Teknologi Malaysia (UTM) on 2003. In September 2005 he joined Universiti Teknikal Malaysia Melaka (UTeM) as a Lecturer at Fakulti Kej. Elektronik dan Kej. Komputer (FKEKK). He received his Master's Degree in Computer and Communication Engineering from University of Nottingham, UK on 2005 and continues his PhD in Electrical and Electronic Engineering in University of Nottingham, UK from 2006 till now. His PhD thesis on the field of Terahertz circuits and devices. Currently he is working on RF and Microwave circuits and devices.

Received 01 August 2012. Published as resubmitted by the authors 23 September 2012. 